\title{
The Effect of Ohmic Heating Pretreatment on Drying of Apple
}

\section{Kutlu, N. ${ }^{\text {a }}$ Yilmaz, M. S. ${ }^{\text {a }}$ Arslan, H..$^{\text {; }}$ Isci, A..$^{a^{*}}$; Sakiyan, O. ${ }^{\text {a }}$}

${ }^{a}$ Ankara University, Department of Food Engineering, Golbasi, Ankara, Turkey

*E-mail of the corresponding author: isci@ankara.edu.tr

\begin{abstract}
In this study, effects of ohmic pretreatment on the drying rates and color kinetics of apple were investigated. Apple slices were treated at different electric field strengths $(20-30$ and $40 \mathrm{~V} / \mathrm{cm})$ at $60^{\circ} \mathrm{C}$ for $1 \mathrm{~min}$. Drying process was applied at $60^{\circ} \mathrm{C}-2 \mathrm{~m} / \mathrm{s}$ by using a tray-dryer. $\Delta E$ and moisture content were calculated. These values were fitted to the semi-theoretical thinlayer drying and the zero and first-order kinetic model. The shortest drying time was found samples treated with $30 \mathrm{~V} / \mathrm{cm}$. Wang\&Singh model gave the superior fit to the experimental data. $\Delta E$ fitted well to the zero-order kinetic model.
\end{abstract}

Keywords: : Ohmic heating, drying, kinetic models, thin-layer models, apple. 


\section{Introduction}

The main purpose of drying is to reduce the water activity in order to extend the shelf life. The dried product has the lowest microbiologic deterioration and enzyme activity.[1] Besides, quality attributes like aroma and the nutritional value are protected by reducing the moisture. The other purpose of the drying process is to provide convenience for transportation and storage via reducing the volume of product.[2] The drying process is generally applied to fruits and vegetables.

The apple which belongs to Rosaceae, the rose family, is a mild season fruit. Apple which has rich antioxidant components, carbohydrates, essential minerals and dietary fiber has a great importance in terms of taste and nutritional value [3]. North Anatolia, Black Sea shore region, Central Anatolia, and East Anatolia plateau are the fields in Turkey which are suitable for apple cultivation. In our country, mainly Starking, Golden Delicious, Star Crimson and Granny Smith are cultivated among 30 strains of apples from all over the world.[4]

Pretreatment of foods before drying takes place to reduce the drying time and also increase the quality of the product. There are different types of pretreatment such as hot-water blanching, osmotic dehydration, ultrasonication. Ohmic heating is one of the newest alternative pretreatment methods.[5-7] With ohmic process, the alternative electric current is passed through the food. The process is also called thermal processing method.[8]

Thin layer drying is the drying of food samples by layer. Thin layer drying has been taken part in several studies in recent years. The reason is the convenience of application and less data requirement.[9]

The main purpose of this study is to pretreat the apple samples (Golden Delicious variety) with ohmic heating and to dry using tray dryer. The samples were pretreated at different electric field strengths $(20,30,40 \mathrm{~V} / \mathrm{cm})$ at $60^{\circ} \mathrm{C}$ for 1 minute. After the pretreatment process, the samples were dried by a tray dryer at $2 \mathrm{~m} / \mathrm{s}$ air velocity at $60^{\circ} \mathrm{C}$. Moisture ratio and changes in color were recorded. These values were fitted to the semi-theoretical thinlayer drying and the zero and first-order kinetic models.

\section{Material and Methods}

\subsection{Material}

Apples used in this study were bought from local market in Ankara, Turkey. They were peeled and cut into slices with dimensions of $15 \times 15 \times 5 \mathrm{~mm}$. The initial moisture content of the fresh apple samples was $85 \pm 1 \%$ (wb) and it was measured by infrared moisture analyzer (MA150, Sartorius, Germany) at $105^{\circ} \mathrm{C}$. 


\subsection{Methods}

\subsubsection{Ohmic Heating Pre-Treatment}

Ohmic heating pretreatment was performed using (CLOH-1000, CLS, Turkey), specially designed and manufactured by Caliskan company. $90 \mathrm{~mL}$ of water was added to the $20 \mathrm{~g}$ of apple sample. Afterwards, apple slices were exposed to different electric field strengths (20, 30 and $40 \mathrm{~V} / \mathrm{cm}$ ) at $60^{\circ} \mathrm{C}$ for $1 \mathrm{~min}$. Samples were filtered and weighed at the and of the process. All experiments were done in duplicates.

\subsubsection{Hot-air Drying}

Hot-air drying was performed in a tray dryer (Eksis, TK-LAB, Turkey). Samples dried without pretreatment was used as a control. The control samples were treated with air at $60^{\circ} \mathrm{C}$ and velocity of $2 \mathrm{~m} / \mathrm{s}$. For the main drying process, the ohmic pretreated samples were dried at $60^{\circ} \mathrm{C}$ and with an air velocity of $2 \mathrm{~m} / \mathrm{s}$. The weight of samples was recorded at 5 min intervals and drying was continued until no further variation in their weight were observed. The dried samples were cooled in desiccators and vacuum packed in heat-sealed low-density polyethylene bags.

\subsubsection{Thin Layer Modelling}

To define drying kinetics of apple samples, dimensionless moisture ratio (MR) values were calculated. MR were determined from moisture content data ( $\mathrm{kg}$ water $/ \mathrm{kg} \mathrm{db}$ ) obtained during drying by using equation 1 :

$$
M R=\frac{M_{t}-M_{e}}{M_{0}-M_{e}}
$$

where, $\mathrm{M}_{\mathrm{t}}, \mathrm{M}_{0}$ and $\mathrm{M}_{\mathrm{e}}$ are the moisture content at time $\mathrm{t}$, the initial moisture content and the equilibrium moisture content of the sample ( $\mathrm{kg}$ water $/ \mathrm{kg} \mathrm{db})$, respectively.

Four different thin layer drying models (Table 1) were applied to drying curves. Sigma plot was used to predict model parameters. The model with the lowest Root Mean Square Error (RMSE) and the chi-square $\left(\mathfrak{x}^{2}\right)$ was defined as the best model describing the thin layer drying behavior of apple.[10] The parameters were calculated using equation 2 and 3.

$$
\begin{aligned}
& R M S E=\left[\frac{1}{N} \sum_{i=1}^{N}\left(M R_{\text {exp } i}-M R_{p r e, i}\right)^{2}\right]^{1 / 2} \\
& x^{2}=\frac{\sum_{t=1}^{N}\left(M R_{e x p, t}-M R_{\text {qre }, t}\right)^{2}}{N-n}
\end{aligned}
$$


where $\mathrm{MR}_{\text {exp;i }}$ and $\mathrm{MR}_{\text {pre; } i}$ are the experimental and predicted moisture ratios of data $i$, respectively. $\mathrm{N}$ is the number of experimental data points and $\mathrm{n}$ is the number of constants in the model.

Table 1. Thin layer models equations

\begin{tabular}{lll}
\hline Model & Model Name & References \\
\hline $\mathrm{MR}=\exp \left(-k t^{n}\right)$ & Page & {$[11]$} \\
$\mathrm{MR}=a \exp (-k t)$ & Henderson and Pabis & {$[12]$} \\
$\mathrm{MR}=a \exp (-k t)+c$ & Logarithmic & {$[13]$} \\
$\mathrm{MR}=1+a t+b t^{2}$ & Wang \& Singh & {$[14]$} \\
\hline
\end{tabular}

\subsubsection{Color Values and Color Kinetics}

The color values of dried and fresh apple samples were measured by using Minolta Color Reader (CR-400, Japan) and expressed as the CIE L*, $a^{*}$, and $b^{*}$ color scale. The average of ten different readings from the same region was reported.

Total color differences were calculated using equation 4 :

$$
\Delta E=\sqrt{\left(L_{0}^{*}-L_{t}^{*}\right)^{2}+\left(a_{0}^{*}-a_{t}^{*}\right)^{2}+\left(b_{0}^{*}-b_{t}^{*}\right)^{2}}
$$

where $\mathrm{L}_{0}^{*}, \mathrm{a}_{0}{ }_{0}, \mathrm{~b}^{*}{ }_{0}$ are the initial color measurements of raw apple samples and $\mathrm{L}_{\mathrm{t}}, \mathrm{a}_{\mathrm{t}}, \mathrm{b}_{\mathrm{t}}{ }_{\mathrm{t}}$ are the color measurements at specified time. $\Delta \mathrm{E}$ values are applied to zero (equation 5 ) and first order (equation 6) kinetic models:[15]

$$
\begin{aligned}
& C=C_{0} \pm k t \\
& C=C_{0} \exp ( \pm k t)
\end{aligned}
$$

where $\mathrm{C}_{0}$ is the initial value of color, $\mathrm{C}$ is the color value at a specified time, $\mathrm{k}$ is the kinetic rate constant and $t$ is time.

\section{Results and Discussions}

The effect of electric field strengths on drying time was depicted in Fig. 1. The results showed that the samples treated with $30 \mathrm{~V} / \mathrm{cm}$ electric field strength was found to have the shortest drying time. Compared to control group, ohmic heating pretreatment have decreased the drying time by 24,35 and $29 \%$ for the samples treated with 20, 30 and 40 $\mathrm{V} / \mathrm{cm}$ electrical field strengths, respectively. It was also observed that moisture ratio decreased continuously with drying time. 


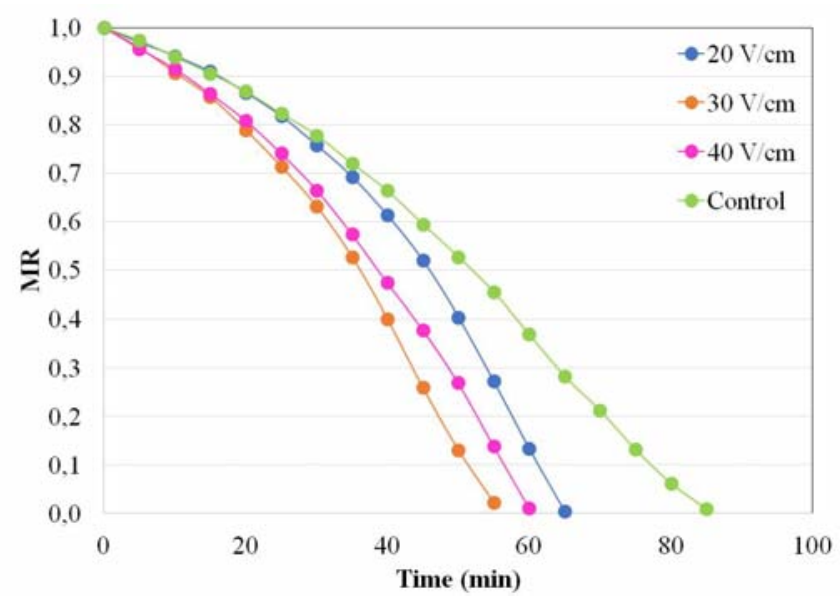

Fig. 1. Effect of electric field strenghts on drying time

The moisture ratio data were fitted to four different thin layer drying models (Table 1). RMSE (Root Mean Square Error), $x_{3}^{2}$ (chi-square) and $\mathrm{R}^{2}$ (coefficient of determination) values were used to compare the relative goodness of fit of experimental data. The results showed that Wang \& Singh model gave the superior fit to the experimental data compared to other models (Table 2). Similar model results were found in the other papers with different drying methods.[16-20]

Table 2. Statistical parameters and coefficients of models at different electrical field strengths for Wang \& Singh model

\begin{tabular}{cccccc}
\hline Process Conditions & RMSE & $\boldsymbol{x}^{2}$ & $\mathbf{R}^{2}$ & $\mathbf{a}$ & $\mathbf{b}$ \\
\hline Control & 0.010166735 & 0.000116283 & 0.9978 & -0.005576 & -0.0000773 \\
$20 \mathrm{~V} / \mathrm{cm}$ & 0.010646449 & 0.000132238 & 0.9983 & -0.001900 & -0.0002048 \\
$30 \mathrm{~V} / \mathrm{cm}$ & 0.001837387 & 0.000004051 & 0.9987 & -0.006242 & -0.0002164 \\
$40 \mathrm{~V} / \mathrm{cm}$ & 0.002985566 & 0.000010534 & 0.9998 & -0.006250 & -0.0001698 \\
\hline
\end{tabular}

Final color values and color kinetics of ohmic pretreated dried apples were determined in the study. The color differences $(\Delta \mathrm{E})$ were calculated by using the measurable color values $\left(\mathrm{L}^{*}, \mathrm{a}^{*}\right.$ and $\left.\mathrm{b}^{*}\right)$ at different electrical field strengths. The $\Delta \mathrm{E}$ values were fitted to zero and first order kinetic models (Fig. 2 and 3). The results showed that the $\Delta \mathrm{E}$ values were fitted well to the zero-order kinetic model. Similar results can also be found in the literature.[2125] 


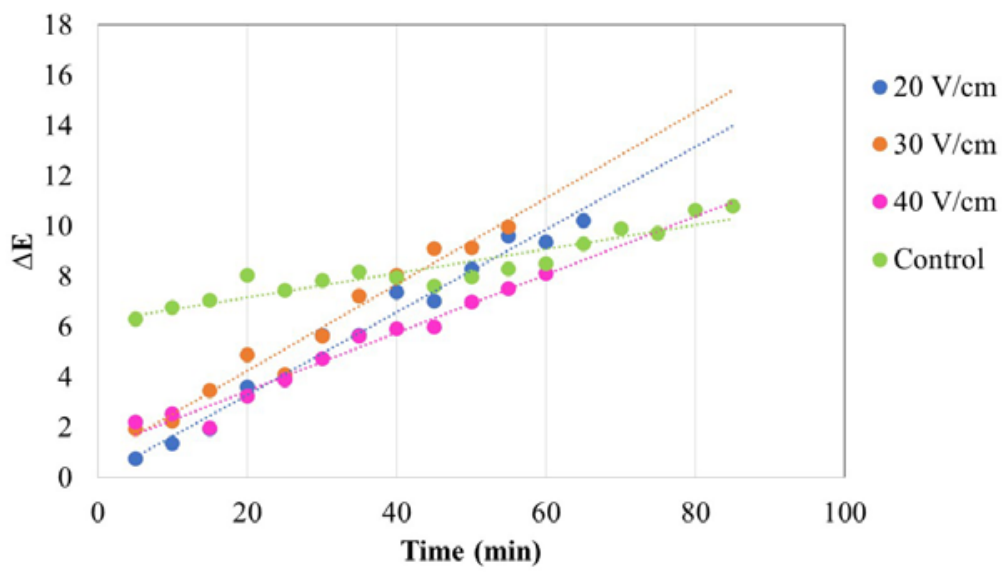

Fig. 2. Zero order kinetic model

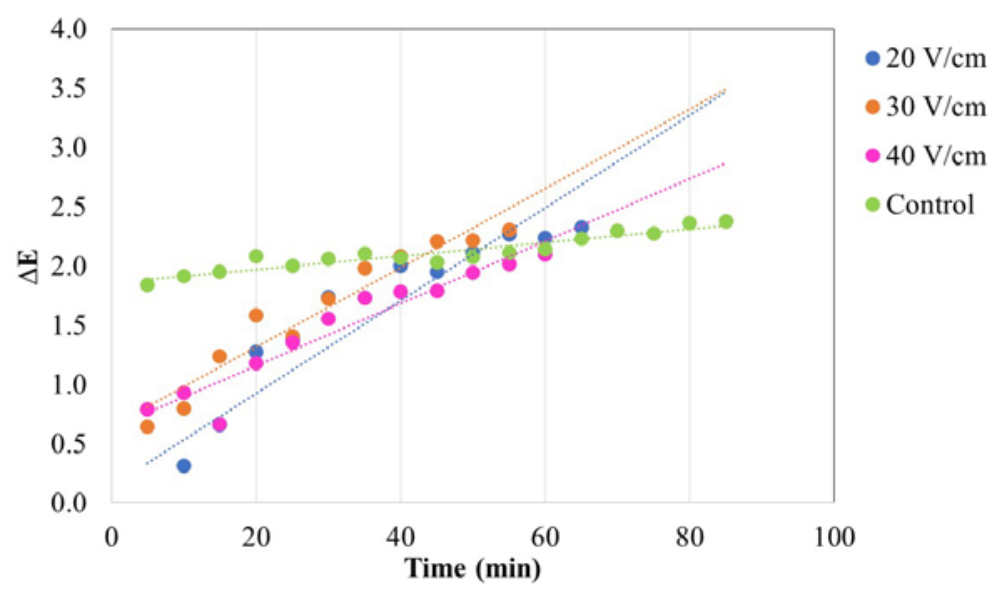

Fig. 3. First order kinetic model

Table 3. Zero and first order kinetic model parameters

\begin{tabular}{ccccc}
\hline Process Conditions & Model & $\mathbf{C}_{\mathbf{0}}$ & $\mathbf{k}$ & $\mathbf{R}^{\mathbf{2}}$ \\
\hline \multirow{2}{*}{ Control } & $\mathrm{C}=\mathrm{C}_{0}+\mathrm{kt}$ & 6.304804 & 0.0490 & 0.8754 \\
& $\mathrm{C}=\mathrm{C}_{0} \exp (-\mathrm{kt})$ & 1.841312 & 0.0057 & 0.8868 \\
\multirow{2}{*}{$\mathbf{V} / \mathbf{c m}$} & $\mathrm{C}=\mathrm{C}_{0}+\mathrm{kt}$ & 0.750296 & 0.1643 & 0.9791 \\
& $\mathrm{C}=\mathrm{C}_{0} \exp (-\mathrm{kt})$ & -0.287290 & 0.0392 & 0.8602 \\
\multirow{3}{*}{$\mathbf{V} / \mathbf{c m}$} & $\mathrm{C}=\mathrm{C}_{0}+\mathrm{kt}$ & 1.903552 & 0.1717 & 0.9710 \\
& $\mathrm{C}=\mathrm{C}_{0} \exp (-\mathrm{kt})$ & 0.643721 & 0.0335 & 0.9291 \\
\multirow{4}{*}{$\mathbf{4 0} \mathbf{V} / \mathbf{c m}$} & $\mathrm{C}=\mathrm{C}_{0}+\mathrm{kt}$ & 2.194434 & 0.1158 & 0.9682 \\
& $\mathrm{C}=\mathrm{C}_{0} \exp (-\mathrm{kt})$ & 0.785924 & 0.0263 & 0.9209 \\
\hline
\end{tabular}




\section{Conclusions}

Ohmic heating is an emerging thermal process technology. Ohmic heating can be used successfully as a pretreatment method in the drying process of food materials. As a conclusion in this study, the samples treated with $30 \mathrm{~V} / \mathrm{cm}$ electric field strength was found to have the shortest drying time. Compared to control group, ohmic heating treatments have decreased the drying time by 24,35 and $29 \%$ for the samples treated with 20, 30 and 40 $\mathrm{V} / \mathrm{cm}$ electrical field strengths, respectively. Wang \& Singh models gave the superior fit to the experimental data compared to other models. In addition, the color values fitted well to the zero-order kinetic model.

\section{Nomenclature}

$\begin{array}{cc}\text { wb } & \text { Wet basis } \\ \mathrm{db} & \text { Dry basis }\end{array}$

\section{References}

[1] Cemeroglu, B.; Özkan, M. 2004. Kurutma teknolojisi, Meyve Sebze İsleme Teknolojisi, 2. Cilt, Cemeroğlu, Bizim Büro Yayınevi, Ankara, Turkey, pp. 479-613.

[2] Ceylan, İ.; Aktaş, M.; Dogan, H. Güneş Enerjili Kurutma Fırınında Elma Kurutulması Journal of Polytechnic, 2006, 9 (4), 289-294.

[3] Coskun, S.; Askın, M.A. Bazı Yerli Elma Çeşitlerinin Pomolojik ve Biyokimyasal Özelliklerinin Belirlenmesi. Süleyman Demirel Üniversitesi Ziraat Fakültesi Dergisi 2016, 11 (1), 120-131.

[4] Mordogan, N.; Ergün, S. Golden ve Starking Elma Çeşitlerinin Şeker İçerikleri ve Bitki Besin Elementleri ile Olan İlişkileri. Ege Üniv. Ziraat Fak. Derg 2002, 39 (1), 103-110.

[5] Salengke, S.; Sastry, S.K. Effect of ohmic pretreatment on the drying rate of grapes and absorption isotherm of raisins. Drying Technology 2005, 23, 551-564.

[6] Icier, F. Ohmic blanching effects on drying of vegetable byproduct. Journal of Food Process Engineering 2010, 33, 661-683.

[7] Jaeger, H.; Roth, A.; Toepfl, S.; Holzhauser, T.; Engel, K.H.; Knorr, D.; Vogel, R.F.; Bandick, N.; Kulling, S.; Heinz, V.; Steinberg, P. Opinion on the use of ohmic heating for the treatment of foods. Trends in Food Science\&Technology 2016, 55, 84-97.

[8] Hosainpour, A.; Darvishi, H.; Nargesi, F.; Fadavi, A. Ohmic pre-drying of tomato paste. Food Sci Technol Int. 2014, 20 (3),:193-204.

[9] Kutlu, N.; İşci, A.; Sakiyan, O. Gıdalarda ince tabaka kurutma modelleri. Gıda 2015, 40 (1), 21-27.

[10] Wang, J.; Xi, Y.S. Drying characteristics and drying quality of carrot using a two- 
stage microwave process. Journal of Food Engineering 2005, 68, 505-511.

[11] Sarsavadiva, P.; Sawhney, R.; Pangavhane, D.R.; Sing, I. Drying behaviour of brined onion slices. J Food Eng 1999, 40, 219-226.

[12] Henderson, S.M.; Pabis, S. Grain drying theory I: Temperature effect on drying coefficient. Journal of Agriculture Research Engineering 1961, 6, 169-174.

[13] Yaldız, O.; Ertekin, C.; Uzun, H.I. Mathematical modeling of thin layer solar drying of sultana grapes. Energy 2001, 26, 457-465.

[14] Wang, C.Y.; Singh, R.P. A Single Layer Drying Equation for Rough Rice. Am. Soc. Agr. Eng. 1978, 78, pp.3001, St. Joseph, MI.

[15] Dadali, G.; Demirhan, E.; Ozbek, B. Color Cahnge Kinetics of Spinach Undergoing Microwave Drying. Drying Technology 2007, 25, 1713-1723.

[16] Soponronnarit, S.; Pongtornkulpanich, A.; Prachayawarakorn, S. Drying characteristics of corn in fluidized bed dryer. Drying Technology 1997, 15 (5), 16031615.

[17] Khawas, P.; Dash, K.K.; Das, A.J.; Deka, S.C. Drying characteristics and assessment of physicochemical and microstructural properties of dried culinary banana slices. International Journal of Food Engineering 2015, 11 (5), 667-678.

[18] Blanco-Cano, L.; Soria-Verdugo, A.; Garcia-Gutierrez, L.M.; Ruiz-Rivas, U. Modeling the thin-layer drying process of Granny Smith apples: Application in an indirect solar dryer. Applied Thermal Engineering 2016, 108, 1086-1094.

[19] Seshachalam, K.; Thottipalayam Velliangiri, A.; Selvaraj, V. Drying of carrot slices in a triple pass solar dryer. Thermal Science 2017, 21 (2), 389-398.

[20] Vijiyan, S.; Thottipalayam Velliangiri, A.; Kumar, A. Thin layer drying characteristics of curry leaves (murraya koenigii) in an indirect solar dryer. Thermal Science 2017, 21 (2), 359-367.

[21] Barreiro, J.A.; Milano, M.; Sandoval, A.J. Kinetics of colour change of double concentrated tomato paste during thermal treatment. Journal of Food Engineering 1997, 33 (3-4), 359-371.

[22] Chutintrasri, B.; Noomhorm, A. Color degradation kinetics of pineapple puree during thermal processing. LWT - Food Science and Technology 2007, 40 (2), 300-306.

[23] Dadali, G.; Demirhan, E.; Özbek, B. Color change kinetics of spinach undergoing microwave drying. Drying Technology 2007, 25, 1713-1723.

[24] Demirhan, E.; Özbek, B. Color change kinetics of microwave-dried basil. Drying Technology 2009, 27, 156-166.

[25] Demirhan, E.; Özbek, B. Color change kinetics of tea leaves during microwave drying. International Journal of Food Engineering 2015, 11 (2), 255-263. 